\title{
Material Flow of Iron in Global Supply Chain
}

\author{
Kenichi NAKAJIMA, ${ }^{1) *}$ Keisuke NANSAI, ${ }^{1)}$ Kazuyo MATSUBAE ${ }^{2)}$ and Tetsuya NAGASAKA ${ }^{2)}$ \\ 1) National Institute for Environmental Studies, 16-2 Onogawa, Tsukuba, Ibaraki, 305-8506 Japan. \\ 2) Graduate School of Engineering, Tohoku University, 6-6-11-1005, Aoba, Aramaki, Aoba-ku, Sendai, Miyagi, $980-8579$ Japan.
}

(Received on June 6, 2014; accepted on July 23, 2014; originally published in Tetsu-to-Hagané, Vol. 100, 2014, No. 6, pp. 750-755)

\begin{abstract}
Recently, sustainable management of resources has become an increasingly recognized issue. Accordingly, interest in understanding the relationship between natural resources consumption and the global product supply chain has also been increasing. Material flow analysis (MFA) is a useful tool for understanding resource consumption and material cycles in national economies. However, detailed MFA studies of the materials embedded in foreign trade flows are rare.

This study identified global trade flow of iron embedded in bilateral trade between 231 countries by multiplying the trade volume of the commodities in the BACl (Base pour l'Analyse du Commerce International) database and the iron content of each commodity. We focused on the cases of Japan, China, and United States, and estimated the mass of iron embedded in imports and export. The identified total flows of iron embedded in international trade were $1.15 \times 10^{9} \mathrm{t}$-Fe with $35.2 \%$ of the flows concentrated in three countries, Japan, China and United States, which are major crude steel production countries.
\end{abstract}

KEY WORDS: material flow analysis; international trade; input-output analysis; supply chain; iron and steel.

\section{Introduction}

Steel is the structural material that shapes society. The production of iron far exceeds that of any other metal. The production of crude steel was $1.41 \times 10^{9} \mathrm{t}^{1)}$ in 2010 , inducing the mining of $2.59 \times 10^{9} \mathrm{t}\left(1.28 \times 10^{9} \mathrm{t}-\mathrm{Fe}\right)^{2)}$ of iron ore. Steel production is closely related to demand for coke ${ }^{3)}$ as a reducing agent as well as nickel, chrome and other alloying elements. ${ }^{4)}$ Rising demand for steel raises concerns about the introduction of environmental problems, such as increased greenhouse gas emissions and the effects of resource mining on biodiversity. ${ }^{3,4)}$ At the same time, better and more efficient use of resources, including recycling, is expected to contribute to reductions in natural resource consumption ${ }^{5)}$ and greenhouse gas emissions ${ }^{6}$ ) throughout the supply chain.

In this context, the supply and demand structure of iron and related substances has been analyzed vigorously by material flow analysis (MFA) techniques, ${ }^{5,7-12}$ ) and the results are shedding light on the overall picture of the use of resources through the supply chain, including the flows and stocks of iron. Representative case studies include, among others, an analysis carried out by Wang et al. ${ }^{7)}$ on 68 countries and regions around the world of flows and stocks of iron and values of flows of iron through international trade and another by Pauliuk et al. ${ }^{8)}$ of the amounts of iron stocks in 200 countries. Except for a few, ${ }^{9-12)}$ many of these MFA studies, including those by Wang et al. and Pauliuk et al., have not sufficiently detailed the flows of material through international trade or the international supply chain, making it extremely difficult to understand the effects of

* Corresponding author: E-mail: nakajima.kenichi@nies.go.jp DOI: http://dx.doi.org/10.2355/isijinternational.54.2657 resource mining prompted by economic activities in each country and environmental emissions on other countries as the relationships among the countries is unclear. Numerous analyses have been carried out for greenhouse gas emissions generated through the supply chain induced by international trade $^{14-17)}$ in the context of discussing the emissions of greenhouse gases. Izard et al. ${ }^{14)}$ discussed a border tax on carbon material based on the flow of iron through international trade for the United States. In contrast, we have proposed a method to obtain a comprehensive understanding of the flows of material through trade by combining a Waste Input-Output Material Flow Analysis model (WIO-MFA) ${ }^{13}$ ) and trade statistics, ${ }^{18)}$ and presented the flow of iron and aluminum through international trade, using Japan as a case example. ${ }^{12)}$ However, a sufficiently comprehensive and detailed analysis of the volume of iron embedded in global trade has yet to be carried out.

Our objective in this study was to illustrate trade relationships of various countries by applying the techniques used in prior studies in order to identify the amount of iron embedded in trade among these countries. Specifically, we identified the worldwide iron flow in global supply chain by analyzing the volume of international trade among the world's 231 countries and regions, and identified the amounts of iron embedded in trade by traded commodities or trade partners for China, Japan and the United States, which are major crude steel producers. ${ }^{19)}$

\section{Analysis Method}

With respect to the volume of international trade, we chose the year 2005 for our analysis as composition infor- 
mation produced by WIO-MFA was available, and extracted import and export volumes $v_{i j}^{(k)}$ for each commodity group in monetary or physical units for 231 countries and regions $(i, j)$, using the BACI (Base pour l'Analyse du Commerce International). ${ }^{20)}$ For commodity groups, we extracted data on approximately 6000 commodity groups published with 6-digit classification numbers by aggregating them to 294 commodity groups (2-digit: 8 commodities; 6-digit: 286 commodities) according to the HS (Harmonized Commodity Description and Coding System) codes. A 6-digit HS classification codes, however, may contain a code that applies to a number of trade goods, and iron-containing goods may be included in them. In order to consider the ratio of iron-containing products in the trade volume of each good $k$ obtained from the BACI, we set a cut-off value $r_{i}^{(k)}$ in the range from 0 to 1 for this study, and multiplied trade volume by this cut-off value in order to increase the accuracy of our estimates of flow of iron-containing goods through trade. The estimates were converted to flow of iron embedded in trade by multiplying the values by the iron content rate $c_{i}^{(k)}$ of each of the goods available from various sources $^{1,2,21)}$ and WIO-MFA. ${ }^{13)}$ That is, we calculated the flow of iron $t_{i j}^{(k)}$ between two countries $(i, j)$ through transactions of the good $k$ via trade as: $t_{i j}^{(k)}=v_{i j}^{(k)} \times r_{i}^{(k)} \times c_{i}^{(k)}$. To validate this estimated volume of flow, we confirmed the material balance of iron in Country $j$ as follows: To explain the input and output of iron in a country simply, input consists of the amounts of iron mined $g_{j}$ in country $j$ and the

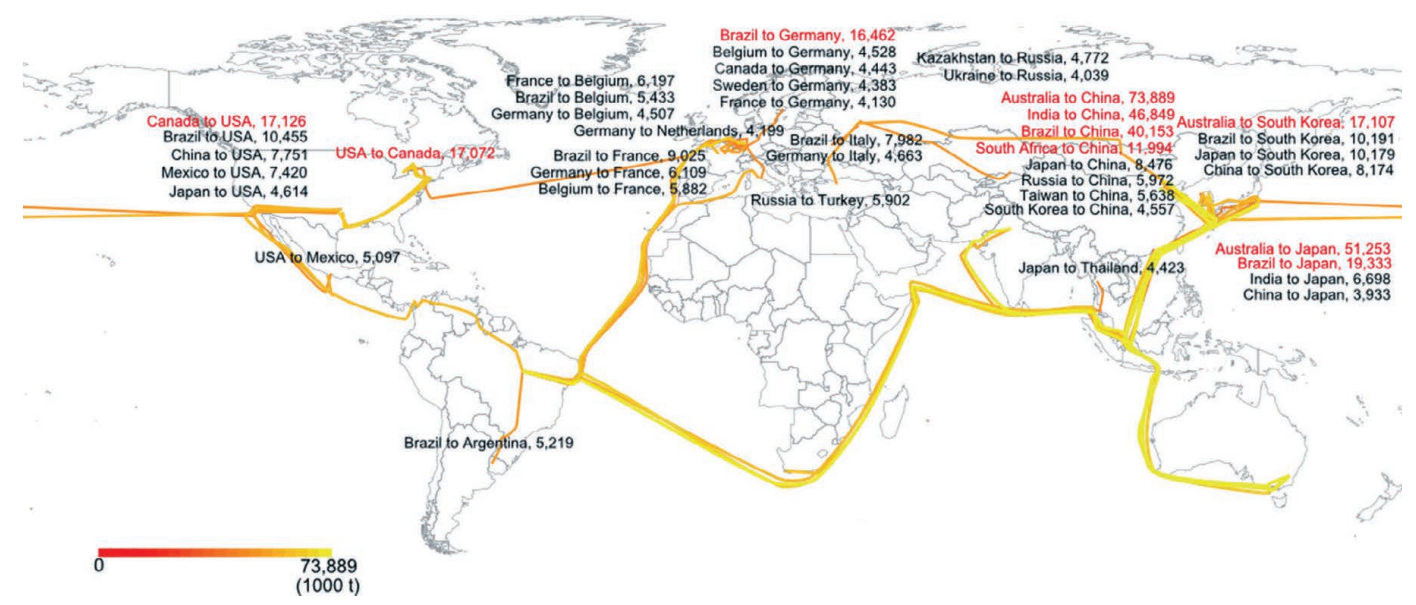

Fig. 1. The 40 largest global flows of iron through international trade in 2005; top 10 flows are indicated in red letters.
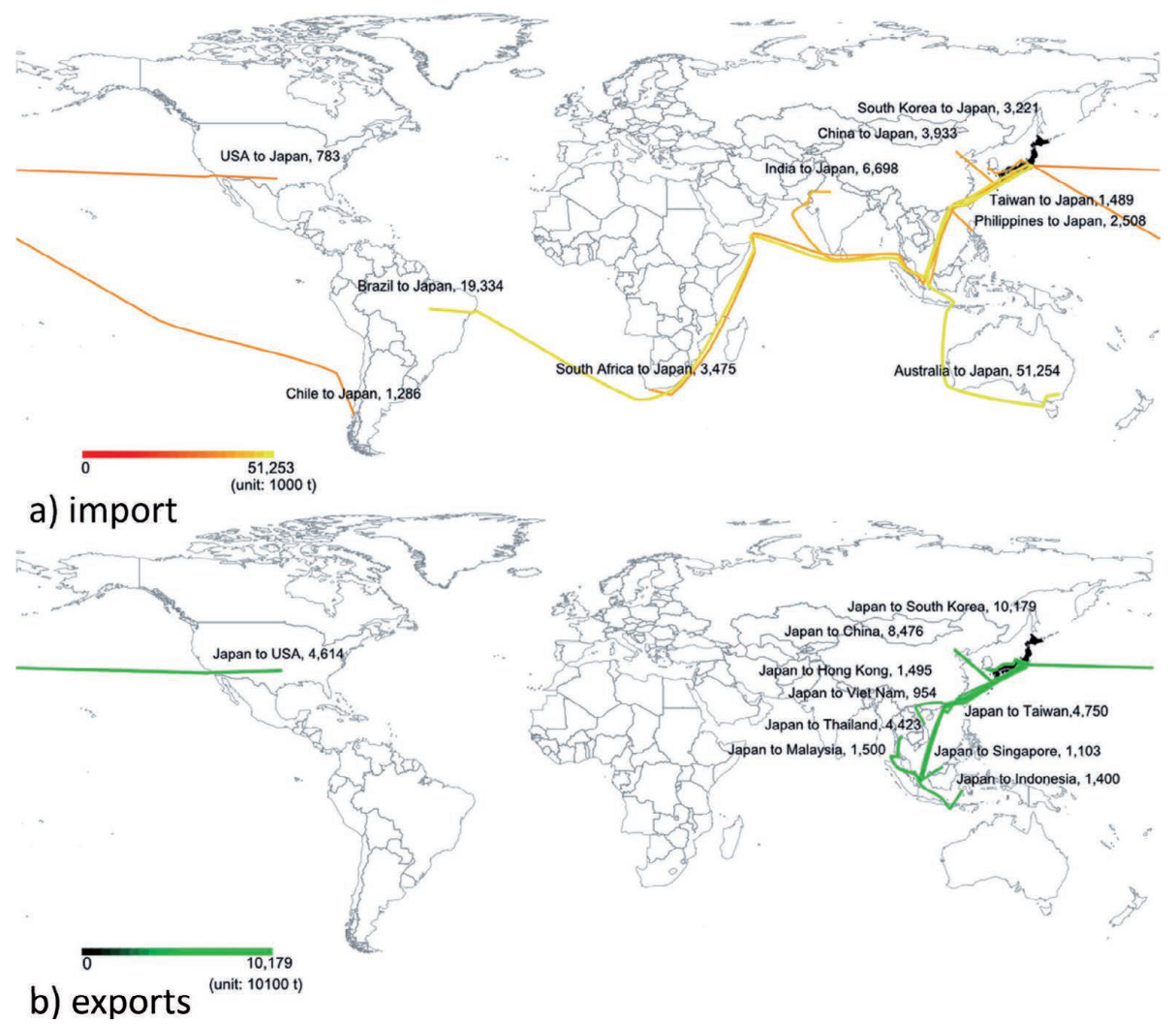

Fig. 2. Top 10 flows of iron embedded in Japanese a) imports and b) exports in 2005. 
iron embedded in imports that was input in country $j m_{j}=$ $\sum_{k} \sum_{i} t_{i j}^{(k)}$, the amount recovered from waste through recycling $w_{j}$, and the amount of iron included in the previous year inventory $z_{j}$. Due, however, to difficulties collecting data, we set the value of $z_{j}$ to 0 in this study. For the output, the amount of iron embedded in export, which exits country $j$, was calculated as: $e_{j}=\sum_{k} \sum_{i} t_{j i}^{(k)}$. The difference after subtracting output from input $s_{j}=g_{j}+m_{j}-e_{j}+w_{j}+z_{j}$ can be construed as the amount of iron that remained in Country $j$ and was input into economic activities of Country $j$, such as production. In principle, the value of $s_{j}$ should be greater than 0 . The value, however, of the result of the above estimation based on limited data was negative, indicating some inconsistency in material balance. In this study, we set the material balance to be $x_{i}^{(k)}=r_{i}^{(k)} \times c_{i}^{(k)}$ and set a constraint condition that the sum of this material balance and the flow of iron would not change from this initial estimated value. The flow of iron $t_{i j}^{*(k)}$ was calculated by adjusting $x_{i}^{(k)}$ using quadratic programming and minimizing the difference with $t_{i j}^{(k)}$ as the sum of squares. We carried out the analysis in this study by using $t_{i j}^{*(k)}$ after eliminating the inconsistency in the material balance.

\section{Results and Discussion}

\subsection{International Supply Chain for Iron}

The result of our analysis indicated that the worldwide flow of iron through trade in 2005 was $1.15 \times 10^{9} \mathrm{t}-\mathrm{Fe}$, of which iron ore accounted for $43.2 \%$ and pig iron and steel $35.5 \%$. In terms of trade flow between countries, transactions between major iron ore producers (Brazil, Australia, India, etc.) and major crude steel producers (China, Japan, US, etc.) ranked high, with the largest 10 flows accounting for $27.2 \%$ of the entire flow of iron among 231 countries and regions, and largest 40 accounting for $43.7 \%$ (Fig. 1). The result also indicate that the flows of iron $\left(0.40 \times 10^{9} \mathrm{t}\right.$ $\mathrm{Fe}$ ) to the largest 3 crude steel producers (China, Japan and US) accounted for $35.2 \%$ of the worldwide flow through trade. These results also signify that the flow of resources was concentrated between several top-ranked countries.

Furthermore, the percentage of the BRICS (Brazil, Russia, India, China and South Africa) and the Next Eleven (N-11: South Korea, Philippines, Pakistan, Iran, Indonesia, Egypt, Turkey, Nigeria, Bangladesh, Vietnam and Mexico) in the worldwide resource flow is worthy of special mention. The BRICS excluding China accounted for $2.8 \%$ in the world's resource imports. Adding the N-11, the percentage of 15 countries was no more than $15.7 \%$. While there is no ques-

Table 1. Proportion of iron embedded in Japanese international trade in 2005, by commodity and country (294 commodities and 230 countries).

\begin{tabular}{|c|c|c|c|}
\hline & Country name & $1000 \mathrm{t}$ & Share, $\%$ \\
\hline \multirow[t]{12}{*}{ Import } & Australia & 51,254 & 52.5 \\
\hline & Brazil & 19,334 & 19.8 \\
\hline & India & 6,698 & 6.9 \\
\hline & China & 3,933 & 4.0 \\
\hline & South Africa & 3,475 & 3.6 \\
\hline & Korea & 3,221 & 3.3 \\
\hline & Philippines & 2,508 & 2.6 \\
\hline & Taiwan & 1,489 & 1.5 \\
\hline & Chile & 1,286 & 1.3 \\
\hline & United States & 783 & 0.8 \\
\hline & Others (220 countries) & 3,605 & 3.7 \\
\hline & Total & 97,586 & \\
\hline \multirow[t]{12}{*}{ Export } & Korea & 10,179 & 24.8 \\
\hline & China & 8,476 & 20.7 \\
\hline & Taiwan & 4,750 & 11.6 \\
\hline & United States & 4,614 & 11.3 \\
\hline & Thailand & 4,423 & 10.8 \\
\hline & Malaysia & 1,500 & 3.7 \\
\hline & Hong Kong & 1,495 & 3.7 \\
\hline & Indonesia & 1,400 & 3.4 \\
\hline & Singapore & 1,103 & 2.7 \\
\hline & Panama & 977 & 2.4 \\
\hline & Others (220 countries) & 11,883 & 29.0 \\
\hline & Total & 50,801 & \\
\hline
\end{tabular}

\begin{tabular}{|c|c|c|c|}
\hline HS-code & Commodity name & $1000 \mathrm{t}$ & Share, $\%$ \\
\hline 260111 & Iron ore, concentrate, not iron pyrites, unagglomerated & 78,515 & 80.5 \\
\hline 260112 & Iron ore, concentrate, not iron pyrites, agglomerated & 6,238 & 6.4 \\
\hline 84 & Nuclear reactors, boilers, machinery, etc. & 1,660 & 1.7 \\
\hline 85 & Electrical, electronic equipment & 1,371 & 1.4 \\
\hline 260300 & Copper ores and concentrates & 1,002 & 1.0 \\
\hline 720110 & Pig iron, non-alloy, $<0.5 \%$ phosphorus & 946 & 1.0 \\
\hline 720839 & Flat rld prod/coils $>3 \mathrm{~mm}$ & 608 & 0.6 \\
\hline 720917 & Flat rld prod/coils $<.5<1$ & 572 & 0.6 \\
\hline 720916 & Flat rld prod/coils $<1>3 \mathrm{~m}$ & 495 & 0.5 \\
\hline 87 & Vehicles other than railway, tramway & 458 & 0.5 \\
\hline- & Others (284 commodities) & 5,721 & 5.9 \\
\hline & Total & 97,586 & \\
\hline 720449 & Ferrous waste or scrap, nes & 4,503 & 8.9 \\
\hline 87 & Vehicles other than railway, tramway & 4,330 & 8.5 \\
\hline 84 & Nuclear reactors, boilers, machinery, etc. & 4,304 & 8.5 \\
\hline 85 & Electrical, electronic equipment & 3,204 & 6.3 \\
\hline 720712 & Semi-finished bars, $\mathrm{i} /$ nas $<0.25 \% \mathrm{C}$, rectangular, nes & 2,684 & 5.3 \\
\hline 720839 & Flat rld prod/coils $>3 \mathrm{~mm}$ & 2,522 & 5.0 \\
\hline 720851 & Flat rld prod $\mathrm{n} /$ coils $<10$ & 2,383 & 4.7 \\
\hline 721049 & Flat rolled i/nas, coated with zinc, width $>600 \mathrm{~mm}$, nes & 2,112 & 4.2 \\
\hline 89 & Ships, boats and other floating structures & 1,824 & 3.6 \\
\hline 720838 & Flat rld prod/coils $<3>4$. & 1,817 & 3.6 \\
\hline \multirow[t]{2}{*}{-} & Others (284 commodities) & 21,118 & 41.6 \\
\hline & Total & 50,801 & \\
\hline
\end{tabular}


tion that resource-rich countries, such as India and Brazil, are included among these countries, these emerging countries have the potential to increase demand as pointed out by Vuuren et $a l^{22)}$ as a result of an expansion of production scale through accelerated industrialization as well as increase in demand for resources with population increases and economic growth. This suggests that iron will also require resource management despite its large reserves.

\subsection{International Iron Supply Chain for Japan, China and the United States}

The three largest crude steel producers in 2005 were China $\left(336 \times 10^{6} \mathrm{t}\right)$, Japan $\left(112 \times 10^{6} \mathrm{t}\right)$ and the United States $\left(94.9 \times 10^{6} \mathrm{t}\right)$, collectively accounting for $48.9 \%$ of the world's crude steel production. This trend remained unchanged in 2010, with the crude steel production of the three largest producers accounting for $57.8 \%$, driven by an increase in production in China.

Figure 2 illustrates Japan's flow of iron through trade and Table 1 shows a breakdown of the flow by country and by commodity group. The flow of iron to Japan embedded in imports was $97.6 \times 10^{6} \mathrm{t}-\mathrm{Fe}$, which included the import of iron ore. In contrast, the flow of iron embedded in exports was $50.8 \times 10^{6} \mathrm{t}-\mathrm{Fe}$ and iron was exported overseas as steel or highly-processed products, such as automobiles, in vol- umes equivalent to $52.1 \%$ of the imports. Flows embedded in imports from Australia and Brazil, which are iron ore producers, accounted for $72.3 \%$ of all iron imports, while exports to South Korea, China and Taiwan accounted for $57.1 \%$ of all exports, underlining the dominance of exports to Asia. By commodity group, iron import in the form of ore accounted for $86.8 \%$ of total imports due to Japan's total dependence on foreign suppliers for iron ore. ${ }^{23)}$ On the export side, highly-processed products accounted for large shares (transportation equipment: 8.5\%; machinery: 8.5\%; electric and electronic equipment: $6.3 \%$ ) in addition to exports of ferrous waste $(8.9 \%)$ and steel. With respect to ferrous waste, increased crude steel production in China drove Japan's export of $4.50 \times 10^{6} \mathrm{t}$-Fe of ferrous waste to that country. Considering that the supply of waste scrap is expected to increase within China in the future, Japan may need to expand its overseas markets or promote domestic recycling.

Although China produces iron ore, it is the largest iron ore importer in the world, ${ }^{23)}$ depending for $58.2 \%$ of its domestic ore consumption on the supply from overseas. Driven by the final demand within China, the percentage of iron exports $\left(51.5 \times 10^{6} \mathrm{t}-\mathrm{Fe}\right)$ to iron imports $\left(228 \times 10^{6} \mathrm{t}-\mathrm{Fe}\right)$ was only $22.6 \%$ (Table 2 ). By country and region, iron imports embedded in iron ore from Australia, India and

Table 2. Proportion of iron embedded in Chinese international trade in 2005, by commodity and country (294 commodities and 230 countries).

\begin{tabular}{|c|c|c|c|}
\hline & Country name & $1000 \mathrm{t}$ & Share, $\%$ \\
\hline \multirow[t]{12}{*}{ Import } & Australia & 73,889 & 32.4 \\
\hline & India & 46,848 & 20.6 \\
\hline & Brazil & 40,153 & 17.6 \\
\hline & South Africa & 11,994 & 5.3 \\
\hline & Japan & 8,476 & 3.7 \\
\hline & Russia & 5,972 & 2.6 \\
\hline & Taiwan & 5,638 & 2.5 \\
\hline & Korea & 4,557 & 2.0 \\
\hline & United States & 3,206 & 1.4 \\
\hline & Republic of Kazakhstan & 3,167 & 1.4 \\
\hline & Others (220 countries) & 23,900 & 10.5 \\
\hline & Total & 227,802 & \\
\hline \multirow[t]{12}{*}{ Export } & Korea & 8,174 & 15.9 \\
\hline & United States & 7,751 & 15.1 \\
\hline & Japan & 3,933 & 7.6 \\
\hline & Hong Kong & 3,701 & 7.2 \\
\hline & Taiwan & 2,975 & 5.8 \\
\hline & Thailand & 2,822 & 5.5 \\
\hline & Indonesia & 1,605 & 3.1 \\
\hline & Vietnam & 1,392 & 2.7 \\
\hline & Singapore & 1,300 & 2.5 \\
\hline & Italy & 1,247 & 2.4 \\
\hline & Others (220 countries) & 16,549 & 32.2 \\
\hline & Total & 51,449 & \\
\hline
\end{tabular}

\begin{tabular}{|c|c|c|c|}
\hline HS-code & Commodity name & $1000 \mathrm{t}$ & Share, \% \\
\hline 260111 & Iron ore, concentrate, not iron pyrites, unagglomerated & 165,221 & 72.5 \\
\hline 260112 & Iron ore, concentrate, not iron pyrites, agglomerated & 21,620 & 9.5 \\
\hline 720449 & Ferrous waste or scrap, nes & 6,129 & 2.7 \\
\hline 720917 & Flat rld prod/coils $<.5<1$ & 3,405 & 1.5 \\
\hline 85 & Electrical, electronic equipment & 2,670 & 1.2 \\
\hline 84 & Nuclear reactors, boilers, machinery, etc. & 2,581 & 1.1 \\
\hline 720839 & Flat rld prod/coils $>3 \mathrm{~mm}$ & 2,472 & 1.1 \\
\hline 720918 & Flat rld prod/coils $>.5 \mathrm{~mm}$ & 2,029 & 0.9 \\
\hline 721049 & Flat rolled i/nas, coated with zinc, width $>600 \mathrm{~mm}$, nes & 1,732 & 0.8 \\
\hline 721030 & Flat rld prod elctr zinc & 1,170 & 0.5 \\
\hline- & Others (284 commodities) & 18,772 & 8.2 \\
\hline & Total & 227,802 & \\
\hline 84 & Nuclear reactors, boilers, machinery, etc. & 5,987 & 11.6 \\
\hline 85 & Electrical, electronic equipment & 5,271 & 10.2 \\
\hline 720712 & Semi-finished bars, $\mathrm{i} /$ nas $<0.25 \% \mathrm{C}$, rectangular, nes & 3,402 & 6.6 \\
\hline 721391 & Bars\&rods, circular cross & 2,519 & 4.9 \\
\hline 720110 & Pig iron, non-alloy, $<0.5 \%$ phosphorus & 2,186 & 4.2 \\
\hline 720711 & Rectangular $\mathrm{i} /$ nas bars, $<.25 \% \mathrm{C}$, width $<$ twice thickness & 2,184 & 4.2 \\
\hline 721420 & Bar/rod, $\mathrm{i} /$ nas, indented or twisted, nes & 1,689 & 3.3 \\
\hline 720851 & Flat rld prod $\mathrm{n} /$ coils $<10$ & 1,454 & 2.8 \\
\hline 720838 & Flat rld prod/coils $<3>4$. & 1,406 & 2.7 \\
\hline 732690 & Articles of iron or steel, nes & 1,371 & 2.7 \\
\hline \multirow[t]{2}{*}{-} & Others (284 commodities) & 23,982 & 46.6 \\
\hline & Total & 51,449 & \\
\hline
\end{tabular}


Brazil accounted for $70.6 \%$ of total imports. On the export side, Asian countries, including South Korea (15.9\%) and Japan (7.6\%), accounted for a large share in addition to exports to the United States (15.1\%). By commodity group, imports of iron ore and ferrous waste accounted for $84.7 \%$, and major export commodities were pig iron and steel materials, machinery and electric/electronic equipment. There are possibilities that future increases in social stock of iron per capita ${ }^{8)}$ could cause Chinese steel production to shift, for example, from meeting domestic demand to exporting, and to adding value to materials and products for that end. Further development and application of our technique to timeseries analysis is expected to help identify these trends.

The United States imported $77.3 \times 10^{6} \mathrm{t}-\mathrm{Fe}$ and exported $41.0 \times 10^{6} \mathrm{t}$-Fe of iron. As domestic production fulfills $80 \%$ of its iron ore requirements, ${ }^{23)}$ the percentage of iron ore imports was only $11.4 \%$, and imports of machinery $(9.5 \%)$ and transportation equipment $(8.6 \%)$ accounted for a higher proportion. By country, Canada, China and Mexico dominated both exports and imports. With respect to imports, the trade-embedded flow of iron from the top four countries, including Brazil, accounted for $55.3 \%$. On the export side, the top three countries, including South Korea, accounted for $53.5 \%$ of the total exports (Table 3). The results of our analysis indicate that the United States has secured resource supply within the country as well as two-way trade connections with its major trade partners.

\section{Conclusions}

For the purpose of identifying trade relationships between countries, we analyzed the global trade flow of iron among world's 231 countries and regions in this study, and identified the international supply chain for iron worldwide. We also examined major crude steel producers China, Japan and the United States, and measured their flows of iron embedded in international trade by commodity or trading partner. The key findings are summarized below.

- Flows of iron to major crude steel producers (China, Japan and the United States) amounted to $35.2 \%\left(0.40 \times 10^{9}\right.$ $\mathrm{t}-\mathrm{Fe})$ of the worldwide flow of iron through trade in 2005 $\left(1.15 \times 10^{9} \mathrm{t}-\mathrm{Fe}\right)$, which indicates the concentration of resource flow. At the same time, the share of the BRICS, excluding China, in the world resource imports was $2.8 \%$. With the addition of the N-11, the share of 15 countries was only $15.7 \%$.

- In Japan, the percentage of iron imports embedded in ore was $86.8 \%$ of iron imports due to the country's total overseas dependence on iron ore. In addition to ferrous waste and steel, exports of transportation equipment,

Table 3. Proportion of iron embedded in United States' international trade in 2005 , by commodity and country (294 commodities and 230 countries).

\begin{tabular}{|c|c|c|c|c|c|c|c|}
\hline & Country name & $1000 \mathrm{t}$ & Share, $\%$ & HS-code & Commodity name & $1000 \mathrm{t}$ & Share, $\%$ \\
\hline \multirow[t]{12}{*}{ Import } & Canada & 17,126 & 22.2 & 84 & Nuclear reactors, boilers, machinery, etc. & 7,359 & 9.5 \\
\hline & Brazil & 10,455 & 13.5 & 87 & Vehicles other than railway, tramway & 6,671 & 8.6 \\
\hline & China & 7,751 & 10.0 & 720110 & Pig iron, non-alloy, $<0.5 \%$ phosphorus & 6,181 & 8.0 \\
\hline & Mexico & 7,420 & 9.6 & 720712 & Semi-finished bars, $\mathrm{i} /$ nas $<0.25 \% \mathrm{C}$, rectangular, nes & 5,159 & 6.7 \\
\hline & Japan & 4,614 & 6.0 & 85 & Electrical, electronic equipment & 4,792 & 6.2 \\
\hline & Russia & 3,289 & 4.3 & 260112 & Iron ore, concentrate, not iron pyrites, agglomerated & 4,622 & 6.0 \\
\hline & Germany & 3,032 & 3.9 & 260111 & Iron ore, concentrate, not iron pyrites, unagglomerated & 4,180 & 5.4 \\
\hline & Korea & 2,912 & 3.8 & 721391 & Bars\&rods, circular cross & 2,172 & 2.8 \\
\hline & Venezuela & 2,176 & 2.8 & 720310 & Ferrous products from direct reduction of iron ore & 1,971 & 2.6 \\
\hline & Taiwan & 1,948 & 2.5 & 721420 & $\mathrm{Bar} / \mathrm{rod}, \mathrm{i} / \mathrm{nas}$, indented or twisted, nes & 1,446 & 1.9 \\
\hline & Others ( 220 countries) & 16,579 & 21.4 & - & Others (284 commodities) & 32,749 & 42.4 \\
\hline & Total & 77,301 & & & Total & 77,301 & \\
\hline \multirow[t]{12}{*}{ Export } & Canada & 17,072 & 33.6 & 260112 & Iron ore, concentrate, not iron pyrites, agglomerated & 6,337 & 15.5 \\
\hline & Mexico & 5,097 & 10.0 & 720449 & Ferrous waste or scrap, nes & 6,140 & 15.0 \\
\hline & China & 3,206 & 6.3 & 84 & Nuclear reactors, boilers, machinery, etc. & 5,445 & 13.3 \\
\hline & Korea & 1,688 & 3.3 & 85 & Electrical, electronic equipment & 2,780 & 6.8 \\
\hline & Turkey & 1,060 & 2.1 & 87 & Vehicles other than railway, tramway & 2,600 & 6.3 \\
\hline & Germany & 922 & 1.8 & 88 & Aircraft, spacecraft, and parts thereof & 1,211 & 3.0 \\
\hline & Japan & 783 & 1.5 & 731815 & Bolts/screws nes, with/without nut/washer, iron/steel & 1,004 & 2.5 \\
\hline & England & 683 & 1.3 & 720410 & Waste or scrap, of cast iron & 875 & 2.1 \\
\hline & India & 638 & 1.3 & 721049 & Flat rolled i/nas, coated with zinc, width $>600 \mathrm{~mm}$, nes & 558 & 1.4 \\
\hline & Malaysia & 598 & 1.2 & 720429 & Waste or scrap, of alloy steel, other than stainless & 555 & 1.4 \\
\hline & Others ( 220 countries) & 9,221 & 18.2 & - & Others ( 284 commodities) & 13,462 & 32.9 \\
\hline & Total & 40,967 & & & Total & 40,967 & \\
\hline
\end{tabular}


machinery and electric/electronic equipment accounted for a high percentage. China imports a large amount of iron ore in addition to mining its own. Iron embedded in ore account for $82 \%$ of the total iron imports. With respect to exports, pig iron/steel and electric/electronic equipment accounted for a large percentage. In the United States, iron imports embedded in machinery and transportation equipment dominated as the country produces iron ore domestically.

Accurate understanding of trends in China and emerging countries will be needed for discussions of the future supply of resources and trade policies, as well as sustainable resource management. The technique used in this study, which utilizes existing statistical information, including international trade statistics, will be useful in gaining overviews before carrying out detailed, high-resolution analyses. The ability of this technique to identify the effects of highlyprocessed products, such as machinery, will also be useful.

Lastly, we conclude this paper by presenting future challenges and outlook. In this study, we processed an extensive volume of information, such as trade flows and composition information, in order to estimate the flow of iron through trading of 294 commodity groups among 231 countries and regions. Each of the data contains uncertainties. Sensitivity analysis based on the uncertainties contained in these data is one of the future challenges. Lenzen et al. ${ }^{11)}$ provide valuable information through their analysis of the use of resources through the supply chain and its effects on biodiversity. We believe that it is possible to carry out a similar analysis in more detail for various metals and materials by improving our technique, which is one of the future challenges for our research.

\section{Acknowledgement}

This study has been made possible by Grant-in-aid for Scientific Research (25241027, 24246150), Environmental Research and Technology Development Fund (S-6-4), and the research project "Resource Logistics as a support tool of Science, Technology and Innovation Policy Decision" of the Research Institute of Science and Technology for Society (RISTEX) of the Japan Science and Technology Agency (JST).

\section{REFERENCES}

1) M. D. Fenton: 2010 Minerals Yearbook IRON AND STEEL, United States Geological Survey, Mineral Commodity Summaries, Reston, VA, (2012), http://minerals.usgs.gov/minerals/pubs/commodity/ iron_\&_steel/myb1-2010-feste.pdf, (accessed 2013-09-20).

2) J. D. Jorgenson: 2010 Minerals Yearbook IRON Ore, United States Geological Survey, Mineral Commodity Summaries, Reston, VA, (2012), http://minerals.usgs.gov/minerals/pubs/commodity/iron_ore/ myb1-2010-feore.pdf, (accessed 2013-09-20).

3) M. Yellishetty, P. G. Ranjith and A. Tharumarajah: Resour. Conserv. Recycl., 54 (2010), 1084.

4) M. Yellishetty, G. M. Mudd and P. G. Ranjith: J. Cleaner Prod., 19 (2011), 78.

5) K. Nakajima, H. Ohno, Y. Kondo, K. Matsubae, O. Takeda, T. Miki, S. Nakamura and T. Nagasaka: Environ. Sci. Technol., 47 (2013), 4653.

6) K. Nakajima, H. Ino and K. Halada: J. Jpn. Inst. Metals, 66 (2002), 701.

7) T. Wang, D. B. Muller and T. E. Graedel: Environ. Sci. Technol., 41 (2007), 5210.

8) S. Pauliuk, T. Wang and D. B. Muller: Resour. Conserv. Recycl., 71 (2013), 22.

9) J. Johnson and T. E. Graedel: J. Ind. Ecol., 12 (2008), 739

10) K. Halada, K. Ijima and N. Kagagiri: J. Jpn. Inst. Met., 73 (2009), 161.

11) M. Lenzen, D. Moran, K. Kanemoto, B. Foran, L. Lobefaro and A. Geshke: Nature, 486 (2012), 109.

12) K. Nakajima, K. Nansai, K. Matsubae, Y. Kondo, S. Kagawa, R. Inaba, S. Nakamura and T. Nagasaka: ISIJ Int., 51 (2011), 1934.

13) S. Nakamura, K. Nakajima, Y. Kondo and T. Nagasaka: J. Ind. Ecol., 11 (2007), 50.

14) C. Izard, C. L. Weber and H. S. Matthews: Environ. Sci. Technol., 44 (2010), 6563.

15) E. G. Hertwich and G. P. Peters: Environ. Sci. Technol., 43 (2009), 6414.

16) J. Guo, L. L. Zou and Y. M. Wel: Energy Policy, 38 (2010), 1389.

17) C. L. Weber, G. P. Peters, D. Guan and K. Hubacek: Energ. Policy, 36 (2008), 3572

18) Ministry of Finance Japan. Trade Statistics of Japan, http://www.customs.go.jp/toukei/info/index.htm, (accessed 2013-09-01).

19) World steel Association, Annual Crude Steel Production 2000-2009, http://www.worldsteel.org/dms/internetDocumentList/statisticsarchive/production-archive/steel-archive/steel-annually/Annual-steel2000-2009/document/Annual\%20steel\%202000-2009.pdf, (accessed 2013-09-20).

20) CEPII: Base pour l'Analyse du Commerce International, http:// www.cepii.fr/anglaisgraph/bdd/baci.htm, (accessed 2013-09-13).

21) JOGMEC: Material Flow of Mineral Resources 2008 (Koubutsu Shigen Material Flow 2008), JOGMEC, Tokyo, (2009).

22) D. P. van Vuuren, B. J. Strengers and H. J. M. De Vries: Resour. Policy, 25 (1999), 239.

23) The Japan Iron and Steel Federation: Handbook for Iron and Steel Statistics 2009, JISF, Tokyo, (2009), 138.

24) The Japan Ferrous Raw Materials Association: Supply and Demand Trends of Steel Scrap in the World, The Japan Ferrous Raw Materials Association, Tokyo, (2013), 27. 